\title{
CABPEMEHO CXBATAњE НАЦИОНАЛНЕ БЕЗБЕДНОСТИ
}

\author{
Гаврило Остојић* \\ Генералштаб Војске Србије, В3 „Мома Станојловић“ \\ Драган Митровић** \\ Генералштаб Војске Србије, ЗОК
}

m

山

ம

рај Хладног рата и нестанак опасности од Совјетског Савеза и сама његова дезинтеграција, донела је нове дилеме око појма безбедности. Безбедносне студије у Европи и САД померио је са бриге за опстанак државе (тзв. „тврда безбедност“) на бригу за економско благостање и просперитет (тзв. „мека безбедност“). Актуелизацији „меког“ приступа безбедности посебно је допринела асиметричне претње безбедности као што су тероризам и организовани криминал, односно процес секуритизације социјалне нестабилности, економских проблема, проблема у вези с миграцијама, угрожавањем животне средине, епидемијама заразних болести и другим појавама и процесима који у традиционалном концепту „тврде“ безбедности нису препознавани као безбедносни процеси и појаве.

Основни предмет рада јесте покушај да приближи савремено схватање националне безбедности односно схватање „меке безбедности“ и то кроз: теорију класичног реализма и неореализма, алтернативни приступи безбедности, конструктивистичке студије и либералне и неолибералне теорије.

Кључне речи: национална безбедност, држава, људска безбедност, национални интереси

\section{Увод}

Шезаустављиви и трајни процес преобликовања безбедности одразио се на промене замисли и концепта безбедности. Држава више није главни предмет интересовања изучавања науке о безбедности. Њено место преузеле су транснационалне и међународне организације, нације, националне мањине, разне професионалне и маргинализоване групе и као најбројнији чиниоци безбедности - појединци. Сразмерно повећању броја референтних објеката безбедности, повећава се и интересовање за културу безбедности. Проширењем списка референтних објеката безбедности, значење појма култура безбедности постаје све сложеније. Више

*gavrilo.ostojic@vzms.vipvo.vs

** dragan.mitrovic@zok.vs 
није главно питање културе безбедности како образовати и васпитати једну нацију у области безбедности, већ како то урадити са сваким појединцем понаособ.

Крај „Хладног рата“" донео је нове дилеме око појма безбедности. Нестанак опасности од Совјетског Савеза, безбедносне студије у Европи и САД помериле су бригу са опстанка државе на бригу о просперитету и економском благостању. Актуелизацији тзв. „меког“ приступа безбедности посебно су допринеле асиметричне претње безбедности као што су тероризам и организовани криминал, процес секуритизације социјалне нестабилности, економских проблема, проблема у вези с миграцијама, угрожавање животне средине, епидемијама заразних болести и другим појавама и процесима који у традиционалном концепту „тврде“ безбедности нису препознавани као безбедносни процеси и појаве.

Од настанка студија безбедности након Другог светског рата па све до осамдесетих година прошлог века, појам безбедности био је готово синоним за слободу од војних претњи националној безбедности. Стратешки мислиоци бавили су се превасходно анализом војних способности и политика своје и других држава у циљу повећања националне безбедности. Војни сектор безбедности представља историјско полазиште студија безбедности и окосницу тзв. стратешких студија. Први концепти и теорије које су развиле академске студије безбедности попут на пример одвраћања, безбедносне дилеме или међусобно загарантованог уништења тицали су се искључиво употребе војне силе и анализе војних претњи. Током трајања гвоздене завесе ${ }^{2}$ нуклеарни сукоб суперсила представљао је претњу која је у други план остављала све остале војне, а поготово не војне изазове безбедности. Завршетком Хладног рата ова претња је драстично умањена, а у први план су доспеле друге војне претње попут грађанског рата, пролиферације оружја за масовно уништење као и не војне претње безбедности.

Када говоримо о сектору војне безбедности мислимо пре свега на динамику између политичких јединица (углавном држава), у којој постоји претња употребе или употреба војне силе. У овом сектору безбедности доминантни су односи војне моћи између ових јединица. Главни објекат у сектору војне безбедности јесте територијални интегритет и суверенитет државе. Претње по овај референтни објекат могу долазити од стране других држава или од стране недржавних актера. Постоје и многи други референтни објекти чија секуритизација може довести до претње или употребе војне силе. Они примарно припадају другим секторима, попут на пример политичког (организациона стабилност политичког поретка) или нивоима на пример међународни либерални економски поредак чија секуритизација може довести до милитаризације односно употребе војне силе. У сектору војне безбедности држава је кључни секуритизујући актер.

\footnotetext{
1 Хладни рат - период развоја међународних односа после Другог светског рата. Означава крајњу заоштреност у односима између великих сила. У његовој основи стајали су супротстављени односи између Сједињених Америчких Држава и Совјетског Савеза, као и успостављање социјалистичког поретка у Источној Европи. Стално је постојала опасност од избијања новог рата светских размера. То је спровођење политике са „позиције силе“ од стране великих држава, ради остваривања политичких циљева, а да ипак не дође до општег ратног сукоба. Карактеришу га обострано неповерење, сумњичавост и неспоразуми.

${ }^{2}$ Гвоздена завеса или Блоковска подела је израз који је популаризовао Винстон Черчил мислећи на границу која је симболично, идеолошки и физички поделила Европу на два одвојена дела од краја Другог светског рата до краја Хладног рата (од 1945. до 1990. године).
} 
Држава настоји да развојем система безбедности обезбеди своју целовитост. Систем националне безбедности има елементе који су претежно окренути решавању унутрашњих безбедносних проблема (полиција, службе безбедности, организације за деловање у ванредним ситуацијама, приватна безбедност, правосудни систем и др.) и елементе који су претежно окренути „према споља“, као што су оружане снаге (војска) и обавештајне службе, које су поред унутрашњих правних норми подвргнуте и међународним нормама. Са општим нормама међународног права морају бити усклађене и унутрашње правне норме којима држава регулише своју безбедност. Држава мора да одговори и билатералним и мултилатералним међународним уговорима које је прихватила у вези са безбедношћу. Све то указује на снажну одређеност система националне безбедности сваке земље међународним обавезама које су прихваћене од надлежних државних органа. Може се закључити да систем националне безбедности представља подсистем ширих друштвених система, на чијим начелима се заснива. Систем националне безбедности представља изузетно сложен систем сачињен од низа подсистема и елемената, који су функционално повезани. ${ }^{3}$

\section{Савремена схватања националне безбедности}

Питање места и улоге безбедности је једно од најважнијих питања опстанка и развоја државе. Систем безбедности као целовита и јединствена делатност сваког конкретног друштва укључује скуп чинилаца и њихових акција у миру, ванредним приликама у рату. Сви чиниоци безбедности међусобно су повезани на основу јединствених начела политичког система и правног поретка земље. Безбедност је у концептуалном смислу, толико спорна, посебно у савременом друштву да није ни приближно могуће пронаћи споразум око њеног значења.

\section{Теорије класичног реализма и неореализма}

У теорији класичног реализма Едвард Кар (Edward Carr) предвиђа јачање егоизма националне државе, пораст међународних сукоба и све мању прилагодљивост међународног права реалности међународних односа. У теорији реализма Кар заузима следеће ставове ${ }^{4}$ :

- либерални рационалисти прошлог века су у својим анализама односа разматрали тадашња претежно хомогена друштава, са слободном трговином, што их је довело до идеалистичког и утопистичког закључка о постојању “природне хармоније интереса”;

- каснији развој, са одбацивањем начела слободног трговања, изоштравао је конфликте интереса, који су решавани само преговорима, што је умањило значај моралних норми у решавању спорова;

\footnotetext{
${ }^{3}$ Душко Томић „Систем националне безбедности“. Пирот: Пи-пресс, 88-94, 2012.

${ }^{4}$ Carr Edward "The twenty years' crisis: 1919-1939". London: Macmillan \& CO. LTD. 1946. http://libarch.nmu.org.ua/bitstream/handle/GenofondUA/19042/e8a4b1dc123b132adcd935bf27f42f5c.pdf?sequ ence=1 (преузето: 23.11.2015.)
} 
- унутрашњи социјални мотиви, незапосленост и расподела дохотка, постају значајнији од максимизације профита, производње и дохотка;

- та тенденција приоритета се преноси и у спољну политику, где све мање добит, а све више "сила" постаје кључни приоритет;

- економска сарадња је све више предмет безбедносних консидерација;

- социјално-економски циљеви нације могу да се остварују само ако се утиче на политике других држава;

- конфликти међу државама могу да се измирују само жртвама интереса међу преговарачима;

- утопистички је замислити поредак заснован на "коалицији" где свака држава покушава да одбрани и потврди свој интерес;

- национални интерес се не поклапа са моралом и "сила" креира морал за заштиту свог интереса;

- питања "силе" су неизразива категоријама морала, мада између сила и морала постоји присутна веза;

- држава води рачуна и о моралу, јер политика заснована само на сили може да изазове само револт других држава;

- сила има примат над моралом;

- да би се створио међународни поредак, издржљив на конфликте, потребно је да једна јединица режима буде знатно "јача" од других јединица (тј. држава) и има превласт која обезбеђује да се у конфлликтима не мора узимати страна.

На теорију Кара, надовезује се и позната теорија Ханса. Моргентауа (Hans Morganthau) реалистичког и структуралистичког опредељења. Он заступа гледиште да национални интерес представља аутономну категорију, која није битније условљена ни домаћим, ни међународним установама

- појам националног интереса садржи два елемента, један "логички" неопходан и статичан, и други "варијабилан", зависан од околности;

- у свету, нације се такмиче за располагање што већом "силом" и ту се јављају сукоби, а спољне политике држава се позивају на "опстанак" као неопходан чинилац националног интереса;

- нације чине све да заштите физички, политички и културни идентитет од угрожавања;

- елементи идентитета чине ентитет назван нација и, стога, интерес нације поставља приоритете и усмерава спољну политику;

- док је међународна заједница организована као заједница националних држава, национални интерес је “последња реч" спољне политике, а нека виша међународна организација тај интерес не може заштитити, јер политика те организације нема могућности да заштити чак ни физички државни опстанак, а нације нису спремне да плате било коју цену за своју независност;

- варијабилни елемент националног интереса може имати мањи или већи утицај на спољну политику, зависно од политичких интереса унутар државе, који су под утицајем интересних група, државних и недржавних установа, а посебно ту и "секторских интереса" и политичких партија;

\footnotetext{
${ }^{5}$ Hans Joachim Morgenthau „In Defense of the National Interest: A Critical Examination of American Foreign Policy Hardcover". University Press of America, 1951.
} 
- легитимност националног интереса се може довести у питање "узурпирањем" тог интереса који, по нивоу, могу имати субнационални, ваннационални и супранационални вид;

- национални интерес може бити узурпиран наднационалним интересом који, код међународних организација нема јак утицај, а повремена поклапања политике државе са политиком међународне организације не представља повиновање државе, већ "случајно подударање";

- потребно је успоставити поредак вредности националног интереса и средстава за њихово извршење, која су оскудна, а при успостављању приоритета варијабилни елементи имају често карактеристику да субјекти настоје да их прикажу као мање или више "неопходне елементе";

- концепт националног интереса не подразумева нити природно усклађену мирну међународну заједницу, нити неизбежност рата, који се минимизује добром дипломатијом.

Класичну теорију реализма, међутим, убрзо замењује неореализам, уоквирен пре свега у делу Кенета Волца (Kenneth Waltz). Он заузима следеће ставове ${ }^{6}$ :

- да би се избегли пропусти "редукционистичких" теорија потребно је применити системски прилаз;

- међународни политички систем треба одвојено разматрати од економског и социјалног, али економске чиниоце треба узимати у обзир код утврђивања "способности" (односно силе) системских јединица, које су (овде) државе;

- потребно је утврдити заједнички чинилац који повезује јединице у целину система;

- основна компонента која прожима јединице је "Принцип поретка" који је део системске структуре;

- поред Принципа поретка, јединице нису једине компоненте, већ пре свега расподела "способности" представља посебну компоненту система;

- структура система садржи:

а) принцип поретка, који првенствено одређује уређење власти и организацију држава (јединица);

б) јединице система (као суверене државе);

ц) дистрибуција способности међу државама;

- разматрање треба да посебно третира “променљиве" јединице, али и променљиве системе;

- да би се добило системско разматрање, потребно је утврдити, апстраховањем конкретних односа јединица, како су ове јединице "аранжиране";

- међународни систем је анархичан (нецентрализован), где се данас јединице система налазе у извесној могућој координацији;

- основно својство јединица су њене функције и задаци, а ове јединице данас имају исте функционалне задатке, али неједнаке способности за њихово извршавање, тако да је системски релевантна само "способност" државе.

\footnotetext{
${ }^{6}$ Waltz Kenneth „Theory of International Politics“. New York: Random House, 64-76, 1979. https://www.press.umich.edu/pdf/9780472099818-ch1.pdf (преузето: 23.12.2015.)
} 
Међународни политички системи се разликују по расподели способности. Способност је индивидуална, а расподела способности је системска карактеристика. Тако имамо системе са мање или више великих сила. Најстабилнији политички међународни систем, је систем са минималним бројем великих сила, а то су две велике силе.

Неореализам напушта ослањање на људску природу. Своје поимање темељи на главним карактеристикама међународне политике у односу на структуру међународног политичког система. ${ }^{7}$ Неореализам полази од следећих претпоставки:

- државе су главни актери у међународној политици;

- државе опстају у структуралној ситуацији међународне анархије, која креира систем самоиспомоћи различит од политике карактеристичне за функционисање унутрашњег простора државе;

- међународна анархија је главни фактор обликовања понашања држава;

- аутохтони фактори ретко кад утичу на спољно понашање држава;

- недржавни (или суб-државни) актери располажу са лимитираном важношћу у светској политици, па чак и тамо где могу да делују - то чине по правилима потпуно програмираним од стране држава;

- стање међународне анархије кажњава државе које се не брину о својим виталним интересима;

- државе располажу са војном силом ради заштите својих виталних интереса;

- државе гравитирају да се понашају као инструментално рационални и ексклузивно јединствени актери;

- државе су преокупиране са опстанком, моћи и безбедношћу;

- државе коегзистирају у сталној „безбедносној дилеми“, па је доста тешко пронаћи прави баланс између дефанзивних способности и анулирања офанзивних претњи супарника;

- државе, будући да су несигурне по питању аспирација других држава, резервисани су у међународној сарадњи - чак и онда када постоји заједнички интереси;

- међународне институције утичу на кооперацију сасвим маргинално, њихов статус није аутономан и устројене су за потенцијалне конфрликте, јер их државе формирају саобразно властитим интересима.

Држава је безбедна ако је опасност насилног нарушавања суштинских вредности државе присутна у оној мери у којој је она способна да одбрани те вредности уз прихватљиве жртве односно по разумној цени и у одсуству непријатељских претњи употребе насиља зарад нарушавања кључних вредности државе. Докле год је међународни систем анархичан, неореалисти су скептични по питању могућности да једна држава у дужем временском периоду не буде суочена са претњама. Због сталног присуства већег или мањег нивоа претњи, безбедност државе почива на могућности да на њих благовремено и ефикасно реагује. Пошто није могуће предвидети намере друге државе и да се те намере, уколико су и познате, могу брзо и радикално променити, неореалисти верују да је планирање безбедности доста компликовано и везано са многобројним потешкоћама. Процена намера потенцијалних ривала мора бити утемељена на анализи најгорег исхода, а виши степен аналитичког поверења мора бити усмерен ка идентификовању материјалних капацитета.

\footnotetext{
${ }^{7}$ Исто као 8.
} 
Кључни моменат у систему самоиспомоћи је одмеравање и/или уравнотежење способности (моћи). Моћна држава која има слабог противника ће своју супериорност и злоупотребити: уцењиваће га, а можда и покорити. Једнаке државне способности условљавају умереност проистеклу на очекивању великих жртава (или цене) агресије. Тако конципирани модел међународне политике условио је ригидно перципирање међународне безбедности. Детерминанта тог положаја је дистрибуција моћи унутар самог система, који се најшире може поделити на униполарну (хегемонистичку), биполарну или мултиполарну системску варијанту. Иако идентификују исте безбедносне проблеме, начин реаговања офанзивних и дефанзивних неореалиста је сасвим различит.

Офанзивни неореалисти директно повезују моћ и безбедност. Ради јачања стабилности, држава мора да максимализује своју релативну снагу и постане супериорна у односу на своје противнике. Држава која располаже са више моћи, статусно ужива већу безбедност. Иако су офанзивни неореалисти скептични су по питању државне кооперације, они је не одбацују у потпуности. Баланс моћи често продукује кооперацију у облику привремених алијанси. Све државе имају агресивне интенције, али немају све државе капацитете да се понашају у складу са таквим интенцијамa.

Дефанзивни неореализам не успоставља директно пропорционалну везу између максимализовања моћи и безбедности (максимализовање моћи под извесним околностима може чак и да значајно штети државама). Државе се бране против претњи и теже минимализовању потенцијалних губитака и заостајања. Експанзионистички покушаји су излишни из угла државне безбедности и могу се завршити са врло неповољним консеквенцијама. Држава треба да одабере најрационалније понашање и избегава претње другима. Наоружавање једне државе, чак и кад је обележено само одбрамбеним аспирацијама, може заплашити друге државе, које то могу доживети као претњу по властиту безбедност и предузети реципрочне мере у третману властите војне силе. Овај офранзивно-дефанзивни баланс је критични фактор у одређивању безбедносне дилеме. Дефанзивни неореалисти пре верују да постоји државна међузависност у реализацији безбедности, него да се она може остварити унилатерарно. Агресивно понашање у међународном систему резултује контра коалицијама које спречавају хегемонистичке циљеве. Време после завршетка Хладног рата огледа се у бројним покушајима усмереним ка модификовању неореалистичке матрице међународне политике. Неокласични реализам са офанзивним неореализмом дели претпоставку да државе на међународну неизвесност реагују потрагом за што већом количином моћи и утицаја. Неокласични реализам уводи две интервенишуће варијабле: перцепцију опасности доносиоца одлука и капацитете државе за мобилисање националних ресурса. Дефанзивни неореализам, употребљава једну од ових варијабли (перцепцију опасности). Дефанзивни неореализам често превиђа фракторе који указују на обликовање перцепције опасности под утицајем релативне материјалне моћи државе.

\footnotetext{
${ }^{8}$ Michae E. Brown, Sean M. Lynn-Jones and Steven E. Miller „The Perils of Anarchy: Contemporary Realism and International Security". MIT Press, Cambridge, 332-376, 1995. https://www.amazon.com/Perils-AnarchyContemporary-International-Security/dp/0262522020 (преузето: 26.02.2016.)
} 


\section{Либералне и неолибералне теорије}

Од Вестфалског уговора ${ }^{9}$ из 1648. године и схватања држава као доминантних представника у међународном систему, постоји значење безбедности као приоритетне обавезе држава. Вестфалски модел представља концепт теоријских приступа међународним односима укључујући неореализам и неолиберални институционализам за које он представља емпиријску правилност. У неореализму, вредности у међународном систему представљају Вестфалске државе, схваћене као национални чиниоци који делују у анархијским околностима и труде се да повећају сопствено благостање и безбедност. Ветфалски модел је претпоставка неолибералног институционализма. Чиниоци Вестфалске државе су уједињени рационални аутономни ентитети који теже да максимално повећају своју сврсисходност, поред ограничења која произлазе из анархијског интернационалног окружења.

Према Џону Локу (John Locke) ${ }^{10}$ човек је разумно биће и слобода је неодвојива од среће. Циљ политике је тражење среће која се одређује кроз категорије мира, хармоније и сигурности. Природно право је једино легитимно, могуће и схватљиво право. У либералном духу, Лок види сврху природног права у функцији очувања и оправдања принципа личне слободе. Природно стање је стање релативног мира, а друштвени уговор који успоставља државу, може бити предмет опозива. Закона и полиције нема у природном стању, већ су они производ грађанског друштва. На међународном плану Џ. Лок помиње федералну власт и могућност разумног међународног права, чија је сврха очување међудржавног мира и опште безбедности.

Шарл Монтескје (Charles-Louis de Secondat, baron de La Brède et de Montesquieu $)^{11}$ продубљује Локову либералну теорију. Пре друштвеног права и закона постоје природна права, као њихов предуслов. Из природе владавине произилазе закони и они зависе од облика власти. Слобода је остварење законитости, а закон је по својој природи продукт разума. Слобода је немогућа ако се две или чак три основне власти нађу у истим рукама где су основне власти: законодавна, извршна и судска. Мир и безбедност подразумева да су три вида власти у равнотежи. Управна власт мора да буде ограничена, да би се осигурала законитост и мир. Није значајно само коме власт припада, већ у којој мери се власт користи. Да би се сачувала слобода личности, њена независност и друштвени мир, потребне су институције које се базирају на сили јавног мњења и подели власти на што широј основи. Поред принци-

\footnotetext{
${ }^{9}$ Вестфалски мир представља серију споразума, којима је завршен Тридесетогодишњи рат. Потписан је 24. октобра 1648. године између цара Фердинанда III, немачких кнежева, представника Холандије, Француске и Шведске. Вестфалски споразум садржи 4 основна принципа:принцип суверенитета нацијадржава и фундаментално право самоопредељења; принцип правне једнакости међу нацијама-државама; принцип обавезујућих међународних уговора међу државама, везујућих уговора; принцип немешања једне државе у унутрашња питања друге државе. Тим уговором створена је база модерног међународног система независних нација-држава. Два најважнија нова принципа су били принцип суверенитета и принцип једнакости нација.

${ }^{10}$ John Locke „Two Treatises of Government”, London: A New Edition, Corrected, 1823. http://socserv.mcmaster.ca/ econ/ugcm/3ll3/locke/government.pdf (преузето: 23.01.2016)

${ }^{11}$ Charles de Secondat Baron de Montesquieu „The Spirit od Laws”, Batoche Books, Kitchener, 2001. http://socserv2.socsci.mcmaster.ca/econ/ugcm/3/l3/montesquieu/spiritoflaws.pdf. (преузето: 23.01.2016.)
} 
па поделе власти уводи се принцип равнотеже, ограничења и контроле власти, што је основа су савременог конституционализма. Неолиберални елемент је потреба за што мањом количином коришћења власти. Друштво не може бити демократско са јаким установама где је власт концентрисана. Са друге стране, ограничење власти је услов легитимитета и мира.

У даљем развоју теорије о безбедности имају све наглашенији међународни аспект. Полазећи од идеје рационалне државе, Имануел Кант (Immanuel Kant) заступа став да се међународна безбедност може очувати кроз друштво или савез држава, над којима би била наддржавна власт тј. држава народа. ${ }^{12}$ Само републикански (демократски) облик власти омогућује мир међу народима. Одавде произилази позната теорија неолиберала да демократије не воде ратове. Посебно је битна улога слободе штампе и јавног мњења, које имају ослонац у разумној природи човека. Сличну теорију либералног облика налазимо код Јохана Фихтеа (Johann Fichte). Државе, засноване друштвеним уговором, коегзистирају међусобно признајући једна другу. Фихте се залаже за федерацију држава које су суверене и не морају ако неће ући у такву наддржавну уговорну творевину. Проширењем ове федерација на целу планету успоставиће се вечни мир, који ће бити заснован на праву сагласном разуму. Стална војска и судство ове наддржавне федерације који би били гарант очувања међународне правде и мира. За даљи развој теорија међународне безбедности значајно је К. Марксово схватање о могућности наоружаног народа и одумирању класичне државе и В. И. Лењиново схватање порекла рата услед противречности развоја међународне привреде. Капитал и његова неједнака концентрација по В. И. Лењину доводе до законите потребе да савремене цикличне привреде теже очувању својих империјалистичких интереса кроз вођење ратова.

Либерални институционализам настао у ери окончања хладног рата, представља теоријски правац истраживања и промишљања новог, проширеног и продубљеног концепта безбедности, при чему се прихватају многе од темељних поставки заговорника реализма. ${ }^{13}$ Либерални институционалисти указују на значај међународне сарадње, посебно оне која се испољава кроз њене мултилатералне облике и институционално удруживање, као најделотворенијих начина за превазилажење насилних сукоба у односима између држава. Одређени значај придају тзв. недржавним субјектима у које се убраја читав спектар невладиних организација, па се чак и појединци сматрају субјектима међународних односа. Доношење одлука у таквим организацијама, посебно утицај на њихово доношење, један је од видова меке моћи у међународним односима. То, заједно са привлачношћу културних добара, идеологије, начина размишљања и живота, чини „привлачност укупног цивилизацијског обрасца“. 14

\footnotetext{
${ }^{12}$ Andrew Hurrell „Kant and the Kantian paradigm in international relations", Review of International Studies. Vol. 16, Issue 3, 183-205. 1990.

https://www.cambridge.org/core/search?q=Kant+and+the+Kantian+paradigm+in+international+relations (преузето: 24.01.2016.)

${ }^{13}$ Андреја Савић и Иван Машуловић „Системи националне безбједности“. Бар: ФПМ, стр. 20, 2010.

${ }^{14}$ Драган Симић „Наука о безбедности - савремени приступи безбједности“. Београд: Службени лист, 37, 2002.
} 
Седамдесетих година двадесетог века долази до поновног оживљавања либералних теорија. Џозеф Нај (Joseph Nye) разликује три врсте либерализма:

- економски

- друштвени, $и$

- политички, у оквиру кога се издвајају институције и демократија. ${ }^{15}$

У економском неолиберализму, државе дефинишу своје интересе на такав начин да се рат сматра неважним за њих. Рат противречи економском развоју. Државе свој положај могу да промене пре путем развоја него путем освајања. „Трговина можда не може да спречи рат, али уводи неке нове навике у погледу пружања нових могућности што може довести до стварања друштвене структуре која је мање склона рату“. ${ }^{16}$ у друштвеној сфрери долази до многих личних контаката који смањују ризик од сукоба и промовишу узајамно разумевање. Супротно наведеном, неореалисти истачу да је и уочи Првог светског рата, дошло до многих контаката међу синдикалистима, банкарима, политичарима, али то није могло да спречи избијање рата. Либерални институционалисти одговарају тврдњом да се слика света данас умногоме разликује од оне из 1914. године. Систему односа међу државама уочи Првог светског рата недостајале су адекватне институције које би обезбедиле оквир у који би се каналисала сва очекивања људи. Стање мира значи већу склоност ка миру и развијање мирољубивих очекивања код људи услед смањења анархичности. Институције смањују анархију, повећавају ред у међународним односима и стабилизују очекивања на четири начина:

- обезбеђују смисао континуитета (даљи раст постојеће институције),

- стварају се могућности за реципроцитет (ни једна трансакција не ствара забринутост због могућности адекватног балансирања),

- обезбеђују адекватан проток информација, и

- обезбеђују начине за разрешавање сукоба.

У другу групу теорија у међународној безбедности спадају плуралне неолибералистичке (институционалистичке) и неофункционалистичке (организационе /кооперативне) теорије. Основни недостаци класичног и каснијег реализма за Ричарда Ешлија (Richard Ashley) су следећи:

- реалистички аргументи/концепти су превише неодређени, "клизави" и неподобни операционим формулацијама и превише су зависни од сензибилитета истраживача појава;

- реализам недовољно одваја субјективне и објективне аспекте политике, при чему субјективне перцепције занемарује, а код неореализма ово се врши и кроз давање приоритета систему;

- реализам се слабо ослања на друштвену теорију, укључујући и социологију и економију;

- реализам запада у слабост аутономности "политичке сфрере" и безбедности, не респектујући економске процесе и не решавајући "политичко-економске" проблеме;

- структуралисти су увек супротстављени феноменалистичким и еволуционистичким знањима, док "свест” субјективитета код структуралиста изазива сумњу;

\footnotetext{
${ }^{15}$ Joseph Nye „Understanding International Conflicts“. New York: Longman, Second Edition, 27-49, 1997.

${ }^{16}$ Исто као 17.
} 
- структурализам интерпретира све са становишта "тотализујућег”, друштвеног и не занима се за конкретну праксу по себи, сводећи је на услове одговорне за битност праксе или постајање праксе битном;

- структуре правилима, по реализму, не регулишу понашање, већ га омогућавају, док јединице (државе) немају идентитет независан од целине; структуралисти врше "апсолутно" раздвајање статичког и динамичког и, евентуално, указују на њихову зависност, где је таква зависност "једносмерна";

- државни центризам је заблуда неореализма, јер не уважава транснационалну "класу" односа и идеолошки се лимитира на аспекте којима се све своди на државне интересе; односно држава претходи међународном систему, где се ова дефинише као јединица, а потом се одређује структура;

- неореализам има недостатке утилитаризма и позитивизма, који објашњавају акцију на инструменталистички начин. ${ }^{17}$

Међу неолибералима укључује се и дијалектички теоретичар Роберт Кокс (Robert Cox) који се сматра и модерним неомарксистом. Његов приступ је недетерминистички марксизам, који се огледа у следећем:

- основа промене у систему је код неореализма неадекватно објашњена, а посебно улога државе и других субјеката;

- у новије време постоји феномен интернационализовања државе, од значаја је конкуренција бирократија/управа и слабљење државе на међународном плану као последице транснационалних мрежа активности;

- за разлику од конфликта у неореализму, који је константан, дијалектички материјализам види у конфликту процес континуираног развоја људске природе и социјалних образаца који мењају правила односа тј. у поређењу са неореализмом где је конфрликт последица структуре, дијалектика види конфрликт као извор промене;

- неореализам недовољно добро увиђа „вертикалну” димензију моћи, који се дијалектички илуструје односом доминације метрополе над периферијом, где данас имамо измењену улогу државе и интернационализацију која је у вези са производним односима;

- историјски материјализам узима у обзир комплексност односа државе и друштва (њихове релације) и проширује виђење односа цивилног друштва и државе. Марксизам уочава утицај и однос економских структурних ограничења и „етичкополитичке" структуре на деловање државе;

- материјализам проучава производни процес као кључни елемент у анализи историјских форми комплекса друштво/држава, а посебно је, с овим у вези, битна и улога производних „снага” која се мора довести у везу са „државном” силом. ${ }^{18}$

Из ових изложених идеја видимо теоријску корелацију са плуралистичким концептима комплексних циљева и мотива акције, као и основе развоја функционализма. Даљи развој теорије међузависности (комплексних мрежа сарадње) допунио је наведена неолиберална схватања.

\footnotetext{
${ }^{17}$ Richard K. Ashley „The poverty of Neorealism“. International Organization, Vol. 38, No. 2. 225-286, 1984. https://ic.ucsc.edu/ rlipsch/Pol272/Ashley.pdf (преузето: 20.01.2016.)

${ }^{18}$ Robert W. Cox „Social Forces, States and World Order u: Neorealism and its Critics“. Millennium - Journal of International Studies, 1996. https://www.uni-erfurt.de/fileadmin/public-docs/Internationale_Beziehungen/cox.pdf (преузето: 20.01.2016.)
} 


\section{Конструктивистичке студије}

Конструктивистичке студије безбедности, сагледавају безбедност као нешто што није дато „од споља“, већ као нешто што је обликовано и (или) преобликовано путем међусобног људског разумевања. Може се говорити о два приступа у оквиру конструктивистичког проучавања безбедности. Прво, државни актери истичу да се безбедност пре може достићи преко заједнице него преко моћи. Заједница претходи претњи и она не може бити створена истом. Безбедност је нешто што може бити конструисано. Друго, је претпоставка да су национални безбедносни интереси дефинисани од стране актера који респондирају аутентичним културним фракторима. Ово не значи да моћ, конвенционално одређена као укупност материјалних капацитета, представља нешто маргинално за анализу националне безбедности, већ да повезаност државе и других актера са моћи и безбедности, помаже да схватимо и објаснимо њихово понашање. ${ }^{19}$

Безбедност је идентификована са културним и цивилизацијским принципима, док је претња (или опасност) дефинисана као одсуство тих начела. Нови концепт безбедности није више искључиво окренут држави, већ је повезан и са схватањем индивидуалних права. Конструктивистички приступ не оповргава релевантност утицаја моћи и интереса на акције и реакције држава, већ констатује да се значајна политичка моћ може експлоатисати из извора који нису војне природе. Тежишну позицију и даље има држава, што имплицира да се културолошко теоретско исходиште конструктивистичке безбедности често користи само као допуна реалистичким теоријама.

\section{Алтернативни приступи безбедности}

Концептуално средиште феминистичког разматрања међународних односа представља тврдња да су по консеквенцама, идентитетима и субјектима које конституишу, међународни односи ултимативно полно профилисани и структуирани. Проблематичност феминистичког приступа безбедности огледа се у методолошки неоснованом позивању на општу женску перспективу априорно применљиву на све жене и у периферности теоретске селекције аспеката међународне безбедности којим се бави.

Поборници пост-структурализма негирају могућност заснивања било каквог чврстог знања које би преовлађивало у расправама о безбедности, због одсуства емпиријски проверљивих хипотеза и тврдњи. За традиционални приступ безбедности, стране које се налазе у сукобу нису актери са различитом вредносном структуром, већ располажу са суштински различитим идентитетима, што резулту-

\footnotetext{
${ }^{19}$ Peter J. Katzenstein „Introduction: Alternative Perspectives on National Security“. NewYork: Columbia University Press, 1-32, 1996. http://www.fb03.uni-frankfurt.de/45503391/Introduction-from-Katzenstein-1996--The-Culture-of-National-Security.pdf (преузето: 23.01.2016.)

${ }^{20}$ Michael C. Desch „Culture Clash: Assessing the Importance of Ideas in Security Studies“. International Security, 23(1), 141-170, 1998. http://n.ereserve.fiu.edu/010009216-1.pdf (преузето: 23.12.2015.)
} 
је различитим погледима на свет. Може се понудити схватање претњи: изнутраспоља, ми-други и домаће-страно (ове моралне зоне су условљене како етичким границама идентитета тако и територијалним границама држава). Из овога угла безбедност је први и најважнији перформативни дискурс за успостављање одређеног политичког поретка. ${ }^{21}$

Концепт људске безбедности се развио из Програма за развој Уједињених Нација (United Nations Development Program - UNDP) донетог 1994. године. ${ }^{22}$ UNDP је предложио измештање фокуса са нуклеарне безбедности на људску безбедност. Завршетак Хладног рата је указао да су многи конфликти лоцирани унутар држава (не на нивоу конфронтације међу државама) питања о апокалиптичној пропасти света, замењена питањима о небезбедности произашлој у свакодневном, обичном животу (на пример да ли ће породице имати шта да једу, да ли ће се сачувати посао, да ли су градови безбедни по питању криминала, да ли ће доћи до тортуре од стране репресивне државе, да ли ће се избећи насиље по религијској, етничкој или полној основи и сл.).

Људска безбедност престала је бити усредсређена на наоружање. Њена базична брига постали су људски живот и достојанство. Указано је на седам области људске безбедности: економску, прехрамбену, здравствену, еколошку, личну, политичку и безбедност заједнице. Главне претње људској безбедности су: неконтролисани раст популације, диспропорција у економским могућностима, миграциони притисци, еколошко назадовање, трговина дрогом и међународни тероризам. UNDP је 1997. године, редефинисао концепт људске безбедности одвајањем доходовног сиромаштва и људског сиромаштва: доходовно сиромаштво подразумева дневни приход од 1 амерички долар или мање, док људско сиромаштво указује на факторе какви су животни век и неписменост. ${ }^{23}$ Академски третман људске безбедности повезао је изучавање конфликата и безбедности са економским развојем. Људска безбедност није само донела преусмеравање концентрисаности са државе на индивидуално, већ и преусмеравање са индивидуалног на индивидуалне потребе. Људска безбедност обухвата са једне стране базичне материјалне потребе (храну, образовање, здравствену заштиту итд.) и са друге стране, постигнућа људског дигнитета, која инкорпорирају личну аутономију, контролу над властитим животом и неометану партиципацију у животу заједнице. ${ }^{24}$

\footnotetext{
${ }^{21}$ David Campbell "Writing Security: United States Foreign Policy and the Politics of Identity“. Manchester: Manchester University Press, 253, 1992.

https://books.google.rs/books?id=q_A2HJA0jmgC\&pg=PA17\&hl=sr\&source=gbs_toc_r\&cad=3\#v=onepage\&q\& $\mathrm{f}=$ false (преузето: 23.01.2016.)

${ }^{22}$ United Nations Development Program „Human Development Report 1994“. New York, Oxford University Press, 1994. http://hdr.undp.org/sites/default/files/reports/255/hdr_1994_en_complete_nostats.pdf (преузето: 23.01.2016.)

${ }^{23}$ United Nations Development Program „Human Development Report 1997“. Oxford University Press, New York, 1997. http://hdr.undp.org/sites/default/files/reports/258/hdr_1997_en_complete_nostats.pdf (преузето: 23.01.2016.)

${ }^{24}$ Thomas Caroline "Global Governance, Development and Human Security: The Challenge of Poverty and Inequality". London: PlutoPress, 2000. http://www.lcs-tcs.com/PDFs/35_1/08-Book\%20Reviews.pdf (преузето: 27.01.2016.)
} 
Безбедносна агенда Копенхашке школе, за разлику од ексклузивне традиционалне оријентисаности на војну безбедност, поред државе као референтног објекта њених анализа, обухвата четири сектора: политички, економски, друштвени и енвиронменталистички. ${ }^{25}$ Идеја друштвене (социјеталне) безбедности је послужила као најефрикаснији начин за целовито разумевање безбедносних задатака у постхладноратовској Европи. ${ }^{26}$ За следбенике ове школе ултимативни критеријум државне безбедности је сувереност, док за друштвену безбедност то представља идентитет. Да би се потпуно разумела таква терминолошка коњункција уведен је и појам секуритизације. $^{27}$ Десриниција и мерила секуритизације се изражавају преко интерсубјективног установљења неке егзистенцијалне претње са потенцираношћу (релевантношћу) довољном да има супстанцијалне политичке ефекте. Студије секуритизације циљају на то да се са повећаном прецизношћу разуме: ко секуритизује, по ком питању (претњи), кога (референтни објекти), зашто, са којим резултатима и под којим условима. Припадници Копенхашке школе искористили су овај образац секуритизације за секторски и више регионални (а мање државни) фокус на безбедност.

Присуство безбедности не значи одсуство небезбедности. Небезбедност је ситуација где постоји претња али нема одбране против ње, а безбедност је ситуација са претњом где постоји одбрана од исте. Безбедност и небезбедност су упућени на каузалну везу претња-одбрана. Повећање безбедности не значи увек смањивање небезбедности. Једини начин да се избегне такав однос јесте прелазак на ниво абезбедности, где нешто уопште није разматрано преко питања о безбедном или небезбедном и где перцепција егзистенцијалне претње уопште није присутна. ${ }^{28}$ Друштво и идентитет се третирају као објективне реалности које се налазе пре споља ради откривања и анализирања, него у стању обликовања и преобликовања од стране променљивих друштвених сила. Идентитет се посматра као нешто реално што егзистира за било које друштво.

Проучавање безбедности у Велшкој школи безбедности, своје утемељење налази у ономе што се одређује као критичка теорија. Разумевање безбедности повезано са појмовима моћи и поретка не успева да било кога учини сигурним. Стално оснаживање „безбедносне дилеме“ чини да сигурност једног актера аутоматски значи несигурност другога. Рат и претња ратом могу се сматрати једном формом те принуде (поред сиромаштва, политичке репресије, слабог образовања и др.). Еманципација и безбедност су лице и наличје једног истог проблема, еманципација, а не ред и поредак, генерише истинску безбедност: теоретски посматрано, еманципација је безбедност. ${ }^{29}$

\footnotetext{
${ }^{25}$ Buzan Barry „People, States and Fear“. Brighton: Harvester Wheatsheaf, 1983.

${ }^{26}$ Buzan Barry, Morten Kelstrup, Pierre Lemaitre and Elzbieta Tromer, Ole Waever "The European SecurityOrder Recast: Scenarios for the Post-Cold War Era“. London: Pinter, 1990.

${ }^{27}$ Waever Ole „Securitization and Desecuritization“, in: Lipschutz Ronnine „On Security“. New York: Columbia University Press, 46-86, 1995. https://s3.amazonaws.com/s3.libraryofsocialscience.com/pdf/Lipschutz-On_Security-3--Waever-Securitization.pdf (преузето: 23.01.2016.)

${ }^{28}$ Waever Ole „Concepts of Security“. Copenhagen: Copenhagen Institute for Political Science, 227, 1997.

${ }^{29}$ Ken Booth "Security and Emancipation“. Review of International Studies, 17 (4), 313-326, Cambridge University Press, 1991. https://www.cambridge.org/core/journals/review-of-international-studies/article/divclasstitlesecurity-and-emancipationa-hreffn01-ref-typefnadiv/7E14C05AF6C58871908F9D48D2F7D973 (преузето: 17.02.2016.)
} 
Париска школа безбедности, указује како се унутрашња и спољна безбедност стапају док се њени спроводиоци надмећу за сукцесивно детериторијализоване задатке полиције, војске и царине. Ствара се нова представа о претњама кроз стално потенцирање проблема са имиграцијом, организованим криминалом и терором. Овај приступ, полази од формулисања области безбедности, идентификовања актера и дефинисања њихових активности. То је омогућило да се одржи корак са савременим друштвом које карактерише све већи степен професионализације и техничке рационалности, где је специфрична социјална позиција привилегована функционисањем у сфери безбедности.

Алтернативни погледи на безбедност деле две одлике: прво - проширују концепт безбедности тако да укључује већи број питања у односу на традиционалну шему фокусираности на војну димензију френомена и друго - продубљују концепт тако да се више односе на референтни објект него на саму државу. Све расправе повезане са феноменом безбедности могу се класификовати у четири групе:

- проширење на доле указује на кретање од нација преко група, ка појединцима;

- проширење на горе указује на кретање од нације ка биосфери;

- хоризонтално проширење обухвата проблеме који се крећу од војске и преносе на политичку, економску, друштвену, еколошку и људску безбедност и

- политичка одговорност за одржавање безбедности је постала потпуно дифузна и подразумева: државе, међународне организације, регионалну или локалну управу, невладине организације, јавно мњење и медије масовне комуникације (интернет, новине, радио и телевизија) и апстрактне природне или тржишне силе.

Овај приступ у први план ставља питање о корисности концепта безбедности. Постоје мишљења која тврде како је појму ускраћена било каква аналитичка вредност, с обзиром на то да више нема подручје суштинског значења, те да је кохерентност у изучавању безбедности екстремно еродирала. ${ }^{30}$ Са друге стране, постоје мишљења која таква теоретска и методолошка проширења у изучавању безбедности држе за нужност, зато што симултано омогућују сужавања у ономе што се заиста тиче безбедности. Вишеслојно разумевање социјалних фактора оних сила које креирају политичку лојалност, пораст претњи и одговарајуће колективне одговоре на њих, отвара и простор за де-секуритизацију: прогресивно измештање безбедносних питања у зону институција и праксе која је удаљена од „голе снаге“, насиља и класичне „безбедносне дилеме“.”

\section{Закључак}

Крај Хладног рата и дезинтеграција СССР, утицале су да безбедносне студије у Европи и САД, све више промовишу - „меку безбедност“. Актуелизацији „меког“ приступа безбедности посебно је допринела асиметричне претње безбедности као што су тероризам и организовани криминал, односно процес секуритизације социјалне

\footnotetext{
30 Baldwin A. David "The Concept of Security". Review of International Studies, 23(1) 5-26, 1997. http://www.princeton.edu/ dbaldwin/selected\%20articles/Baldwin\%20(1997)\%20The\%20Concept\%20of\%20Se curity.pdf (преузето: 23.01.2016.)

${ }^{31}$ Keith Krause and Michael C. Wiliams „Broadening the Agenda of Security Studies: Politics and Methods“. Mershon International StudiesReview, 40(2), 229-254, 1996.

https://www.moodle.stoa.usp.br/mod/resource/view.php?id=48581 (преузето: 23.02.2016.)
} 
нестабилности, економских проблема, проблема у вези с миграцијама, угрожавање животне средине, епидемије заразних болести и другим појавама и процесима који у традиционалном концепту „тврде“ безбедности нису препознавани као безбедносни процеси и појаве. На овај начин, ново-савремено схватање „мека безбедност“ на велика врата улази у безбедносне науке, што потврђује и чињеница да се све већи примат даје бризи за просперитет и економско благостање државе, над војним претњама по националну безбедност.

\section{Лumepamypa}

[1] Душко Томић „Систем националне безбедности“. Пирот: Пи-пресс, 88-94, 2012.

[2] Carr Edward „The twenty years' crisis: 1919-1939“. London: Macmillan \& CO. LTD. 1946. http://libarch.nmu.org.ua/bitstream/handle/GenofondUA/19042/e8a4b1dc123b132adcd935bf27f42f 5c.pdf?sequence=1 (преузето: 23.11.2015)

[3] Hans Joachim Morgenthau "In Defense of the National Interest: A Critical Examination of American Foreign Policy Hardcover". University Press of America, 1951.

[4] Waltz Kenneth „Theory of International Politics“. New York: Random House, 64-76, 1979. https://www.press.umich.edu/pdf/9780472099818-ch1.pdf (преузето: 23.12.2015)

[5] Michae E. Brown, Sean M. Lynn-Jones and Steven E. Miller „The Perils of Anarchy: Contemporary Realism and International Security“. MIT Press, Cambridge, 332-376, 1995. https://www.amazon.com/Perils-Anarchy-Contemporary-International-Security/dp/0262522020 (преузето: 26.02.2016)

[6] John Locke „Two Treatises of Government”, London: A New Edition, Corrected, 1823. http://socserv.mcmaster.ca/ econ/ugcm/3ll3/locke/government.pdf (преузето: 23.01.2016)

[7] Charles de Secondat Baron de Montesquieu "The Spirit od Laws”, Batoche Books, Kitchener, 2001. http://socserv2.socsci.mcmaster.ca/econ/ugcm/3/l3/montesquieu/spiritoflaws.pdf. (преузето: 23.01.2016)

[8] Andrew Hurrell „Kant and the Kantian paradigm in international relations", Review of International Studies. Vol. 16, Issue 3, 183-205. 1990.

https://www.cambridge.org/core/search?q=Kant+and+the+Kantian+paradigm+in+international+rela tions (преузето: 24.01.2016)

[9] Андреја Савић и Иван Машуловић „Системи националне безбједности“. Бар: ФПМ, стр. 20, 2010.

[10] Драган Симић „Наука о безбедности - савремени приступи безбједности“. Београд: Службени лист, 37, 2002.

[11] Joseph Nye „Understanding International Conflicts“. New York: Longman, Second Edition, 27-49, 1997.

[12] Richard K. Ashley „The poverty of Neorealism“. International Organization, Vol. 38, No. 2. 225-286, 1984. https://ic.ucsc.edu/ rlipsch/Pol272/Ashley.pdf (преузето: 20.01.2016)

[13] Robert W. Cox "Social Forces, States and World Order u: Neorealism and its Critics“. Millennium - Journal of International Studies, 1996. https://www.uni-erfurt.de/fileadmin/publicdocs/Internationale_Beziehungen/cox.pdf (преузето: 20.01.2016)

[14] Peter J. Katzenstein "Introduction: Alternative Perspectives on National Security“. NewYork: Columbia University Press, 1-32, 1996. http://www.fb03.uni-frankfurt.de/45503391/Introduction-fromKatzenstein-1996---The-Culture-of-National-Security.pdf (преузето: 23.01.2016) 
[15] Michael C. Desch "Culture Clash: Assessing the Importance of Ideas in Security Studies“. International Security, 23(1), 141-170, 1998. http://n.ereserve.fiu.edu/010009216-1.pdf (преузето: 23.12.2015)

[16] David Campbell "Writing Security: United States Foreign Policy and the Politics of Identity". Manchester: Manchester University Press, 253, 1992.

https://books.google.rs/books?id=q_A2HJA0jmgC\&pg=PA17\&hl=sr\&source=gbs_toc_r\&cad=3\#v= onepage\&q\&=false (преузето: 23.01 .2016 )

[17] United Nations Development Program „Human Development Report 1994“. New York, Oxford University Press, 1994.

http://hdr.undp.org/sites/default/files/reports/255/hdr_1994_en_complete_nostats.pdf (преузето: 23.01.2016)

[18] United Nations Development Program „Human Development Report 1997“. Oxford University Press, New York, 1997.

http://hdr.undp.org/sites/default/files/reports/258/hdr_1997_en_complete_nostats.pdf (преузето: 23.01.2016)

[19] Thomas Caroline „Global Governance, Development and Human Security: The Challenge of Poverty and Inequality". London: PlutoPress, 2000. http://www.lcs-tcs.com/PDFs/35_1/08Book\%20Reviews.pdf (преузето: 27.01.2016)

[20] Buzan Barry „People, States and Fear“. Brighton: Harvester Wheatsheaf, 1983.

[21] Buzan Barry, Morten Kelstrup, Pierre Lemaitre and Elzbieta Tromer, Ole Waever „The European SecurityOrder Recast: Scenarios for the Post-Cold War Era“. London: Pinter, 1990.

[22] Waever Ole "Securitization and Desecuritization“, in: Lipschutz Ronnine „On Security“. New York: Columbia University Press, 46-86, 1995.

https://s3.amazonaws.com/s3.libraryofsocialscience.com/pdf/Lipschutz--On_Security-3--WaeverSecuritization.pdf (преузето: 23.01.2016)

[23] Waever Ole "Concepts of Security“. Copenhagen: Copenhagen Institute for Political Science, 227, 1997.

[24] Ken Booth „Security and Emancipation“. Review of International Studies, 17 (4), 313-326, Cambridge University Press, 1991. https://www.cambridge.org/core/journals/review-ofinternational-studies/article/div-classtitlesecurity-and-emancipationa-hreffn01-reftypefnadiv/7E14C05AF6C58871908F9D48D2F7D973 (преузето: 17.02.2016)

[25] Baldwin A. David „The Concept of Security“. Review of International Studies, 23(1) 5-26, 1997. http://www.princeton.edu/ dbaldwin/selected\%20articles/Baldwin\%20(1997)\%20The\%20Concept \%20of\%20Security.pdf (преузето: 23.01.2016)

[26] Keith Krause and Michael C. Wiliams „Broadening the Agenda of Security Studies: Politics and Methods". Mershon International StudiesReview, 40(2), 229-254, 1996.

https://www.moodle.stoa.usp.br/mod/resource/view.php?id=48581 (преузето: 23.02.2016) 